\title{
BACKLOADING - ZMIANA ZASAD AUKCJI UPRAWNIEŃ DO EMISJI
}

\section{BACKLOADING - CHANGE IN THE RULES FOR AUCTIONS OF EMISSION ALLOWANCES}

\section{STRESZCZENIE}

Przyjęty w roku 2009 pakiet energetyczno-klimatyczny określił ambitne cele w zakresie redukcji emisji co najmniej do roku 2020. Podstawą zreformowanego EU ETS stała się aukcja uprawnień do emisji, będąca wyrazem rynkowego charakteru tego systemu. Kryzys finansowy przyczynił się do znacznego ograniczenia emisji gazów cieplarnianych oraz spadku cen uprawnień do emisji. W celu podniesienia ich ceny oraz poprawienia opłacalności inwestycji w odnawialne źródła energii Komisja dąży do przyjęcia środków modyfikujących regulacje pakietu energetyczno-klimatycznego. Proponowane rozwiązania ad-

" Magister, Kancelaria Salans FMC SNR Denton Oleszczuk Sp. k. w Warszawie. 
ministracyjne polegające na zmianie harmonogramu aukcji uprawnień wydają się naruszać jednak prawo traktatowe oraz zasady, na których oparty został system handlu uprawnieniami do emisji. Artykuł przedstawia argumenty przemawiające przeciwko przyjęciu projektu tej regulacji.

\section{Słowa kluczowe}

System handlu emisjami, aukcja uprawnień do emisji, backloading, reforma EU ETS, zakres kompetencji Komisji.

\section{ABSTRACT}

The energy and climate package which was approved in 2009 defined ambitious target for reducing greenhouse gas emissions at least by 2020. The basis of the reformed EU ETS has become the auction of emissions allowances which is based on market mechanism. The financial crisis led to a significant reduction in greenhouse gas emissions and lower prices of the emission allowances. In order to raise of the EUAs price and improve the profitability of investment in renewable energy sources Commission aims to the adoption of the legislation that modifies the energy and climate package. The proposed administrative solutions consisting of change auctioning schedule seem to violate the treaty law and the principles on which was based EU ETS. This article presents the arguments against the adoption of the draft this legislation.

\section{Keywords}

EU Emissions Trading System, auctioning of emission allowances, backloading, reform of the EU ETS, scope of the Commission competence.

\section{PODSTAWY PRAWNE AUKCJI UPRAWNIEŃ DO EMISJI}

W dniu 23 stycznia 2008 r. Komisja Europejska (Komisja) przedstawiła zestaw propozycji legislacyjnych, na podstawie których 23 kwietnia 2009 r. przyjęto tzw. pakiet energetyczno- 
-klimatyczny ${ }^{1}$. Zgodnie z jego założeniami do 2020 r. Unia Europejska (UE) powinna w szczególności: (i) zredukować o co najmniej 20\% emisje gazów cieplarnianych poniżej poziomów z 1990 roku (i o ok. 30 \%, pod warunkiem że inne kraje rozwinięte zobowiążą się do porównywalnej redukcji emisji), (ii) zwiększyć do 20\% udział energii odnawialnej w finalnej konsumpcji energii, oraz (iii) zwiększyć efektywność energetyczną o $20 \%$, w stosunku do prognoz na 2020 rok.

Jednym z kluczowych elementów pakietu energetyczno-klimatycznego odnoszącym się do emisji gazów cieplarnianych stała się dyrektywa Parlamentu Europejskiego i Rady 2009/29/ WE z dnia 23 kwietnia 2009 r. zmieniająca dyrektywę 2003/87/ WE w celu usprawnienia i rozszerzenia wspólnotowego systemu handlu uprawnieniami do emisji gazów cieplarnianych (Dyrektywa 2009/29/WE). Zgodnie z art. 10 ust. 1 Dyrektywy 2009/29/WE podstawową metodą rozdziału uprawnień w tzw. trzecim okresie rozliczeniowym unijnego systemu handlu uprawnieniami do emisji gazów cieplarnianych (EU ETS) obejmującym lata 2013-2020 jest aukcja uprawnień do emisji. Sprzedażą na aukcji objęte zostały uprawnienia nieprzydzielo-

1 Na pakiet energetyczno-klimatyczny składają się w szczególności: dyrektywa Parlamentu Europejskiego i Rady 2009/29/WE z dnia 23 kwietnia 2009 r. zmieniająca dyrektywę 2003/87/WE w celu usprawnienia i rozszerzenia wspólnotowego systemu handlu uprawnieniami do emisji gazów cieplarnianych, Dz.Urz. UE L 140 z 05.06.2009, s. 63 ze zm.; decyzja Parlamentu Europejskiego i Rady nr 2009/406/WE w sprawie wysiłków podjętych przez państwa członkowskie, zmierzających do zmniejszenia emisji gazów cieplarnianych w celu realizacji do roku 2020 zobowiązań Wspólnoty dotyczących redukcji emisji gazów cieplarnianych, Dz.Urz. UE L 140 z 05.06.2009, s. 136 ze zm.; dyrektywa Parlamentu Europejskiego i Rady 2009/31/WE z dnia 23 kwietnia 2009 r. w sprawie geologicznego składowania dwutlenku węgla oraz zmieniająca dyrektywę Rady 85/337/EWG, dyrektywy Parlamentu Europejskiego i Rady 2000/60/WE, 2001/80/WE, 2004/35/WE, 2006/12/ WE, 2008/1/WE i rozporządzenie (WE) nr 1013/2006), Dz.Urz. UE L 140 z 05.06.2009, s. 114 ze zm.; dyrektywa Parlamentu Europejskiego i Rady 2009/28/WE z dnia 23 kwietnia 2009 r. w sprawie promowania stosowania energii ze źródeł odnawialnych zmieniająca i w następstwie uchylająca dyrektywy 2001/77/WE oraz 2003/30/WE), Dz.Urz. UE L 140 z 05.06.2009, s. 16 ze zm. 
ne bezpłatnie, co oznacza odejście od obowiązującej dotychczas w ramach EU ETS zasady bezpłatnego rozdziału uprawnień.

Zgodnie ze zmianami wprowadzonymi przez Dyrektywę 2009/29/WE do dnia 30 czerwca 2010 r. Komisja zobowiązana została do przyjęcia rozporządzenia określającego zasady aukcji uprawnień do emisji. Przyjęcie rozporządzenia we wskazanym terminie miało zapewnić przeprowadzenie sprzedaży aukcyjnej w sposób otwarty, przejrzysty, zharmonizowany i niedyskryminujący. W tym celu proces ten powinien być przewidywalny, w szczególności w odniesieniu do harmonogramu oraz przebiegu aukcji oraz szacunkowego wolumenu uprawnień, które mają być udostępnione ${ }^{2}$.

Zasady sprzedaży uprawnień na aukcji określone zostały w rozporządzeniu Komisji (UE) nr 1031/2010 z dnia 12 listopada 2010 roku w sprawie harmonogramu, kwestii administracyjnych oraz pozostałych aspektów sprzedaży na aukcji uprawnień do emisji gazów cieplarnianych na mocy dyrektywy 2003/87/ WE Parlamentu Europejskiego i Rady ustanawiającej system handlu przydziałami emisji gazów cieplarnianych we Wspólnocie (rozporządzenie 1031/2010) ${ }^{3}$.

Stabilne rozwiązania dotyczące aukcjoningu uprawnień do emisji oraz wyznaczone przez pakiet energetyczno-klimatyczny ramy, w tym 20\% redukcja emisji gazów cieplarnianych, miały na celu zwiększyć poziom przewidywalności dla inwestycji ograniczających emisje do $2020 \mathrm{r}$.

Tymczasem spadek cen uprawnień do emisji ${ }^{4}$ (EUA) wywołał lawinę inicjatyw legislacyjnych ${ }^{5}$ na poziomie UE zmierza-

2 Zob. treść podstawy prawnej wydania Rozporządzenia 1031/2010.

3 Dz.Urz. UE L 302 z 18.11.2010, s. 1 ze zm.

4 EUA - [ang. european union allowances] odpowiednik emisji 1 tony dwutlenku węgla. Do spadku cen uprawnień do emisji (do ok 4-5 EUR/EUA) przyczyniło się spowolnienie gospodarcze i mniejsze emisje z sektorów uczestniczących w EU ETS. Efektem tego stało się powstanie tzw. nadwyżki uprawnień do emisji, która według szacunków Komisji Europejskiej na koniec roku 2011 wynosiła 955 mln uprawnień.

5 Zob. np. Plan działania na rzecz wprowadzenia konkurencyjnej gospodarki opartej na technologiach niskoemisyjnych do 2050 r." (KOM(2011)0112) oraz towarzyszące mu dokumenty robocze (SEC(2011) 0288) i (SEC(2011) 0289); Komunikat Komisji do Parlamentu Europejskiego, Rady, Europejskiego 
jących do rewizji ustaleń przyjętych w ramach pakietu energetyczno-klimatycznego. Działania te mają na celu implementację środków rewizyjnych zarówno o charakterze tymczasowym (zmierzającym do zmiany harmonogramu aukcji uprawnień tzw. backloading), jak i o charakterze długotrwałym (tzw. reforma strukturalna $)^{6}$, mogących skutkować co do zasady zaostrzeniem ww. 20\% celu redukcji emisji.

W ramach działań o charakterze tymczasowym prowadzone są prace nad wnioskiem legislacyjnym mającym doprowadzić do przesunięcia puli uprawnień przeznaczonych na aukcje $\mathrm{z}$ lat 2013 - 2015, na lata $2019-2020^{7}$ (zmiana ustalonego harmonogramu aukcji). Wniosek ten obejmuje projekt decyzji Parlamentu Europejskiego i Rady zmieniającej Dyrektywę 2003/87/ WE w celu wyjaśnienia przepisów dotyczących harmonogramu aukcji uprawnień do emisji gazów cieplarnianych (Projekt zmia-

Komitetu Ekonomiczno-Społecznego i Komitetu Regionów - Plan działania w zakresie energii do roku $2050 \mathrm{KOM(2011)} 885$ wersja ostateczna; Dokument z dnia 27 marca 2013 r. Zielona Księga - Ramy polityki w zakresie klimatu i energii do roku 2030 [KOM(2013) 169 wersja ostateczna].

6 W zakresie działań o charakterze strukturalnym (długotrwałym) zapowiedziano przedstawienie na koniec roku 2013 projektów legislacyjnych, które mogą skutkować wyraźną zmianą celu redukcji emisji z 20 do 30\% do roku 2020, usunięciem na trwałe z EU ETS części EUA, rewizją liniowego współczynnika redukcji uprawnień wynoszącego obecnie $1,74 \%$ rocznie, objęcia przez EU ETS dodatkowych sektorów (np. instalacji spalania paliw o mocy poniżej $20 \mathrm{MW}$ ), dalszego ograniczenia możliwości rozliczania emisji jednostkami ERU (wygenerowane w ramach projektów wspólnych wdrożeń) i CER (wygenerowane w ramach projektów mechanizmu czystego rozwoju), czy też wprowadzenia dyskrecjonalnych mechanizmów zarządzania EUA (np. w postaci minimalnej ceny EUA). Zob. Sprawozdanie Komisji dla Parlamentu Europejskiego i Rady z dnia 14 listopada 2012 r. - Stan europejskiego rynku uprawnień do emisji dwutlenku węgla w 2012 r. [COM(2012) 652 wersja ostateczna].

7 Zob. wniosek legislacyjny Komisji z dnia 25 lipca 2012 r. zmierzających do przesunięcia uprawnień do emisji, obejmujący wniosek dotyczący decyzji Parlamentu Europejskiego i Rady zmieniającej dyrektywę 2003/87/ WE w celu wyjaśnienia przepisów dotyczących harmonogramu aukcji uprawnień do emisji gazów cieplarnianych [COM(2012)0416 - C7-0203/20122012/0202(COD)]. Aktualna wersja zob. teksty poprawki przyjęty przez Parlament Europejski w trakcie posiedzenia w dniu 3 lipca 2013, P7_TA-PROV(2013)07-03, http. 
ny Dyrektywy 2003/87/WE) oraz projekt rozporządzenia Komisji zmieniającego rozporządzenie (UE) nr 1031/2010 zwłaszcza w celu określenia wolumenu uprawnień do emisji, które mają zostać sprzedane na aukcji w latach 2013-2020 (Projekt zmiany Rozporządzenia 1031/2010") ${ }^{8}$. Proponowane rozwiązania zbiorczo określa się jako tzw. backloading.

Powyższe inicjatywy legislacyjne są niezwykle istotne przy podejmowaniu strategicznych decyzji dotyczących działalności objętych przez EU ETS ${ }^{9}$. Dotyczy to w szczególności takiego kraju jak Polska, w którym ponad 90\% energii wytwarzanej jest z wysokoemisyjnego węgla. Ewentualne zaostrzenie obowiązującej regulacji wspierać będzie wzrost ceny EUA. To z kolei przekłada się na wzrost kosztów prowadzenia działalności i spadek konkurencyjności danej branży na globalnym rynku. Daleko idące konsekwencje zmiany harmonogramu aukcji skłaniają do bliższego przyjrzenia się podstawom prawnym tej inicjatywy legislacyjnej.

\section{OCENA PROJEKTU ZMIANY ZASAD AUKCJI}

\subsection{PROJEKT I JEGO UZASADNIENIE}

Zgodnie z aktualnym brzmieniem projektu zmian dyrektywy 2003/87/WE, który wprowadzić ma zmiany do jej art. 10 ust. 4, dotyczącego sprzedaży uprawnień do emisji na aukcji „Jeżeli ocena skutków dla poszczególnych sektorów przemysłu wskazuje, że nie należy spodziewać się znaczącego wpływu na sektory lub podsektory narażone na wysokie ryzyko ucieczki emisji, Komisja może w wyjątkowych okolicznościach dostosować harmonogram okresu, o którym mowa w art. 13 ust. 1, en.pdf.

8 http://ec.europa.eu/clima/policies/ets/reform/docs/2013_07_08_

9 EU ETS obejmuje w zasadzie wszystkie podstawowe sektory działalności przemysłowej, począwszy od energetyki, przemysłu rafineryjnego, przemysłu hutniczego czy cementowego. 
rozpoczynającego się 1 stycznia 2013 r. w taki sposób, aby zapewnić prawidłowe funkcjonowanie rynku. Komisja dokonuje tylko jednego dostosowania tego typu na maksymalną liczbę 900 milionów uprawnień"10.

$\mathrm{Na}$ podstawie tak zmienionych przepisów Dyrektywy 2003/87/WE ${ }^{11}$ Komisja po spełnieniu dodatkowych przesłanek (czyli po wystąpieniu wyjątkowych okoliczności, które jak można mniemać, zakłócają „prawidłowe funkcjonowanie rynku”, oraz po wykonaniu analizy wykazującej brak wpływu backloadingu na sektory i podsektory narażone na wysokie ryzyko ucieczki emisji) uzyska prawo do wprowadzenia jednorazowej modyfikacji harmonogramu aukcji w zakresie maksymalnie $900 \mathrm{mln}$ EUA. Do bezpośredniego wdrożenia backloadingu konieczne będzie więc przyjęcie przez Komisję odpowiedniej zmiany do Rozporządzenia 1031/2010. Zmiana ta polegać ma na dodaniu do Rozporządzenia 1031/2010 załącznika II (w postaci tabeli). W tabeli przedstawiono sposób przeprowadzenia zmiany harmonogramu aukcji poprzez wskazanie zarówno poziomów redukcji EUA kierowanych na aukcje (w latach: 2013 o $400 \mathrm{mln}$, 2014 o $300 \mathrm{mln}, 2015$ o $200 \mathrm{mln}$ ) i odpowiednio poprzez wskazanie wolumenów EUA kierowanych „powrotnie” na aukcje (w 2019 o $300 \mathrm{mln}$ i 2020 o $600 \mathrm{mln}$ ).

W związku z tym, że aukcje uprawnień w trzecim okresie rozliczeniowym stanowią główny mechanizm, za pomocą którego następuje dystrybucja wszystkich wygenerowanych EUA (odpowiadających poziomowi zobowiązań UE w zakresie redukcji gazów cieplarnianych do roku 2020), opóźnienie takie wpływa

10 Zgodnie z poprawką dotyczącą art. 10 ust. 4 akapit pierwszy zdanie ostatnie, przyjętą przez Parlament Europejski w dniu 3 lipca 2013 r. w sprawie wniosku dotyczącego decyzji Parlamentu Europejskiego i Rady zmieniającej dyrektywę 2003/87/WE w celu wyjaśnienia przepisów dotyczących harmonogramu aukcji uprawnień do emisji gazów cieplarnianych (COM(2012)0416 C7-0203/2012 - 2012/0202(COD)) Artykuł 10 - ustęp 4 - akapit pierwszy ostatnie zdanie.

11 Dyrektywa 2003/87/WE Parlamentu Europejskiego i Rady z dnia 13 października 2003 r. ustanawiająca system handlu przydziałami emisji gazów cieplarnianych we Wspólnocie oraz zmieniająca dyrektywę Rady 96/61/ WE; Dz.Urz. L 275 z 25.10.2003, s. 32 ze zm., Polskie wydanie specjalne, rozdz. 15, t. 7, s. 631 (Dyrektywa 2003/87/WE). 
bezpośrednio na liczbę uprawnień, jaka w poszczególnych latach trzeciego okresu rozliczeniowego trafiałaby na rynek. To z kolei (uwzględniając reguły podaży i popytu) przekładać się powinno na odpowiednią zmianę ceny EUA, a więc i koszty po stronie podmiotów zobowiązanych do ich pozyskania.

Zgodnie $\mathrm{z}$ uzasadnieniem ${ }^{12}$ projektu backloadingu regulacja ta zmierza do poniesienia ceny EUA. Spowolnienie gospodarcze ograniczyło bowiem popyt na dostępne na rynku EUA, co przełożyło się na spadek ich ceny. Zdaniem Komisji ten spadek ceny nie umożliwia wystarczającego wspierania trwałych innowacji naukowych i technologicznych oraz przyczynia się do ograniczania zachęt do inwestowania w technologie niskoemisyjne oraz do zwiększania ryzyka uzależnienia UE od technologii wysokoemisyjnych. Tymczasem przy określaniu ram obowiązującej regulacji ustawodawca unijny nie przewidział takiego scenariusza.

\subsection{OCENA PODSTAW FORMALNOPRAWNYCH}

Powyższą inicjatywę legislacyjną oceniać można z punktu widzenia jej zgodności z wymaganiami proceduralnymi, jak i z punktu widzenia jej zgodności z podstawowymi założeniami EU ETS oraz celami Dyrektywy 2003/87/WE.

$\mathrm{W}$ analizie formalnoprawnych podstaw backloadingu, kluczowe znaczenie mają postanowienia 290 oraz 291 Traktatu o Funkcjonowaniu Unii Europejskiej ${ }^{13}$ (TFUE), za pomocą których wyznaczono zakres kompetencji prawodawczych Komisji.

Zgodnie z art. 290 TFUE „Akt ustawodawczy może przekazywać Komisji uprawnienia do przyjęcia aktów o charakterze nieustawodawczym o zasięgu ogólnym, które uzupełniają lub zmieniają niektóre, inne niż istotne, elementy aktu ustawodawczego. Akty ustawodawcze wyraźnie określają cele, treść, zakres oraz czas obowiązywania przekazanych uprawnień. Przekaza-

12 http://www.europarl.europa.eu/sides/getDoc.do?type=REPORT\&reference $=$ A7-2013-0046\&language $=$ PL.

13 Wersja skonsolidowana, Dz.Urz. UE. C 326 z 26.10.2012; s. 47. 
nie uprawnień nie może dotyczyć istotnych elementów danej dziedziny, ponieważ są one zastrzeżone dla aktu ustawodawczego. Z kolei zgodnie z art. 291 ust. 2 TFUE „Jeżeli konieczne są jednolite warunki wykonywania prawnie wiążących aktów Unii, akty te powierzają uprawnienia wykonawcze Komisji [...]". W świetle tych regulacji wyróżnić można: a) uprawnienia przekazywane Komisji w celu przyjęcia aktów o charakterze nieustawodawczym o zasięgu ogólnym, które uzupełniają lub zmieniają niektóre, „inne niż istotne”, elementy aktu ustawodawczego (tzw. akty delegowane) - (art. 290 ust. 1 TFUE), oraz b) uprawnienia powierzone Komisji w celu przyjęcia tzw. aktów wykonawczych (art. 291 ust. 2 TFUE).

W związku z tym, że Rozporządzenie 1031/2010 jest nieustawodawczym delegowanym aktem prawnym ${ }^{14}$, to zgodnie z art. 290 TFUE taki akt delegowany, nie może wprowadzać zmian lub uzupełnień istotnych elementów danej dziedziny, ponieważ są one zastrzeżone dla aktu ustawodawczego. Z punktu widzenia wymagań proceduralnych ocena dopuszczalności przyjęcia aktu prawnego wprowadzającego zmiany do Rozporządzenia 1031/2010 uwzględniać powinna w szczególności treści konkretnej zmiany. Treść ta powinna pozostawać w zgodzie z charakterem aktu delegowanego. W konsekwencji delegowany akt prawny zmieniający lub uzupełniający istotne elementy aktu ustawodawczego (w naszym przypadku Dyrektywy 2003/87/WE) powinien być uznany za niezgodny z postanowieniami art. 290 ust. 1 TFUE.

14 Na charakter Rozporządzenia 1031/22010 jako nieustawodawczego aktu delegowanego wskazuje chociażby treść 10 ust. 4 Dyrektywy 2003/87/ WE będącego podstawą do jego wydania. Zgodnie z treścią ww. art. 10 ust. 4, przepisy wydane przez Komisję na tej właśnie podstawie mają „na celu zmianę elementów innych niż istotne niniejszej dyrektywy poprzez jej uzupełnienie [...]. Powyższe ustalenia odnośnie charakteru prawnego uprawnień Komisji znajdują potwierdzenie również w motywie (45) Dyrektywy 2009/29/WE. Zgodnie z jego postanowieniami Komisji należy przyznać uprawnienia do przyjęcia środków dotyczących harmonizacji zasad określania [...] sprzedaży uprawnień na aukcji, tymczasowego przydziału uprawnień w całej Wspólnocie [...]. Środki te mają zasięg ogólny i „mają na celu zmianę elementów innych niż istotne" dyrektywy 2003/87/WE między innymi poprzez jej uzupełnienie nowymi, innymi niż istotne elementami. 
TFUE nie definiuje pojęcia „istotnych elementów” danej regulacji. Natomiast zgodnie z orzecznictwem Trybunału Sprawiedliwości Unii Europejskiej (TSUE), analizującym bezpośrednio kwestie kompetencji Komisji do wydawania aktów delegowanych „[...] przyjmowanie istotnych norm w rozpatrywanej dziedzinie jest zastrzeżone do kompetencji prawodawcy Unii [...]. Istotne przepisy danej dziedziny powinny być przyjmowane $\mathrm{w}$ drodze uregulowania podstawowego i nie podlegają delegacji". [...] Wynika stąd, że przepisy wykonawcze ani nie mogą zmieniać istotnych elementów uregulowania podstawowego, ani uzupełniać go poprzez nowe istotne elementy. Kwestia, które elementy danej dziedziny należy zakwalifikować jako istotne, nie podlega [...] wyłącznie ocenie prawodawcy Unii, lecz musi opierać się na obiektywnych czynnikach, które mogą zostać poddane kontroli sądowej"15.

Z orzecznictwa TSUE wynika więc, iż prawodawca unijny (Parlament Europejski i Rada) delegując uprawnienia regulacyjne dla Komisji, nie ma swobody co do zakresu takiej delegacji. W szczególności nie możne decydować o tym, iż dane kwestie mają charakter nieistotny, gdy w świetle postanowień danej regulacji mają one znaczenie kluczowe dla danego aktu, regulując jego ,istotne elementy”.

Czy w takim razie projekt backloadingu zmierza do regulacji istotnych elementów Dyrektywy 2003/87/UE? W świetle analizy kluczowych przepisów Dyrektywy 2003/87/WE można przyjąć, że tak.

Powyższa konkluzja znajduje uzasadnienie w szczególności w świetle postanowień art. 9 Dyrektywy 2003/87/WE, który reguluje niezwykle istotną kwestię, jaką jest liczba wydawanych w ramach EU ETS uprawnień do emisji. Zgodnie z ww. art. 9 „Począwszy od 2013 r., liczba wydawanych corocznie w całej Wspólnocie uprawnień ulega zmniejszeniu w sposób liniowy, przy czym za punkt wyjścia przyjmuje się wartość z połowy okresu 2008-2012. Liczba uprawnień ulega zmniejszeniu o współczynnik liniowy wynoszący $1,74 \%$ w odniesieniu do średniej

15 Zob. wyrok TSUE z dnia 5 września 2012 r. w sprawie w sprawie C-355/10, pkt 64-67 oraz przywołane tam orzecznictwo. 
całkowitej rocznej liczby uprawnień wydanych przez państwa członkowskie zgodnie z decyzjami Komisji dotyczącymi ich krajowych planów rozdziału uprawnień na lata 2008-2012 [...]".

Zgodnie z motywem (13) Dyrektywy 2009/29/WE uzasadnieniem dla takiego rozwiązania jest to, by system unijny uczestniczył w sposób kosztowo efektywny w realizacji zobowiązania UE do łącznej redukcji emisji o 20\% do 2020 roku.

Zgodnie z akapitem 3 art. 9 Dyrektywy 2003/87/WE Komisja dokonuje przeglądu współczynnika liniowego i w stosownych przypadkach, począwszy od 2020 r., przedstawia Parlamentowi Europejskiemu i Radzie wniosek w celu przyjęcia decyzji do $2025 \mathrm{r}$.

Uwzględniając powyższe regulacje, uzasadniony jest wniosek, iż liczba uprawnień wydawanych w poszczególnych latach trzeciego okresu rozliczeniowego (2013-2020) została z góry ustalona. Dodatkowo, Dyrektywa 2003/87/WE wyraźnie podkreśla konieczność utrzymania (nienaruszalności) określonego $(1,74 \%)$ liniowego współczynnika redukcji emisji ${ }^{16}$ co najmniej do 2020 r. Możliwość przeprowadzenia przeglądu ww. współczynnika liniowego dopuszczona została wyraźnie dopiero po 2020 r. Z uwagi na powyższe nie powinno być wątpliwości, iż rozwiązania prawne określające liczbę uprawnień do emisji, jakie powinny być udostępnione na rynku w poszczególnych latach trzeciego okresu rozliczeniowego, są regulacjami istotnymi dla aktu ustawodawczego, jakim jest Dyrektywa 2003/87/ WE. Rozwiązania te są ściśle powiązane z celami ${ }^{17}$ Dyrektywy 2003/87/WE oraz ze sposobem realizacji zobowiązań redukcyjnych UE.

Powyższa zasada corocznej liniowej redystrybucji uprawnień do emisji, których liczba zostaje określona na podstawie

16 Zasada liniowej określonej (1,74\%), korekty liczby uprawnień ma zastosowanie również do uprawnień wydawanych bezpłatnie - zob. np. art. 10a ust. 7 Dyrektywy 2003/87/WE - „Liczba przydzielonych uprawnień jest korygowana współczynnikiem liniowym, o którym mowa w art. 9”.

17 Zgodnie z art. 1 Dyrektywy 2003/87/WE, ustanawia ona system handlu przydziałami emisji gazów cieplarnianych we Wspólnocie w celu wspierania zmniejszania emisji gazów cieplarnianych w efektywny pod względem kosztów oraz skuteczny gospodarczo sposób. 
określonego współczynnika redukcji, znajduje potwierdzenie również na gruncie obowiązujących przepisów Rozporządzenia 1031/2010 wyznaczającego ramy obowiązującego systemu aukcyjnego.

Zgodnie z motywem (20) Rozporządzenia 1031/2010 wolumen uprawnień, które mają być sprzedawane na aukcji każdego roku, powinien zasadniczo ${ }^{18}$ odpowiadać wolumenowi uprawnień przypisanych na ten rok. Zgodnie z motywem (21) Rozporządzenia 1031/2010, zgodnie z popytem na rynku wtórnym wolumen uprawnień, które mają być sprzedawane na aukcji w każdym roku, powinien być równomiernie rozłożony na cały ten rok.

Powyższa zasada równomiernego rozkładu z góry określonego wolumenu uprawnień pomiędzy poszczególnymi latami oraz $\mathrm{w}$ danym roku okresu rozliczeniowego, rozwinięte zostały nie tylko w motywach, lecz również w tekście Rozporządzenia 1031/2010. Przykładowo zgodnie z jego art. 7, w przypadku uprawnień objętych przepisami rozdziału III Dyrektywy 2003/87/WE (dotyczącego instalacji stacjonarnych) wolumen do sprzedania na aukcji jest rozdzielany równomiernie na cztery najbliższe zaplanowane aukcje. W przypadku uprawnień objętych przepisami rozdziału II Dyrektywy 2003/87/WE (odnoszącego się do sektora lotniczego) wolumen do sprzedania na aukcji jest rozdzielany równomiernie na dwie najbliższe zaplanowane aukcje.

Zgodnie z art. 8 ust. 5 Rozporządzenia 1031/2010 „najpóźniej od szóstej aukcji wolumen uprawnień sprzedawanych na aukcji na platformie aukcyjnej [...] jest rozdzielany równomiernie na aukcje odbywające się w danym roku [...]".

Zgodnie z art. 10 Rozporządzenia 1031/2010 („Roczny wolumen uprawnień objętych przepisami rozdziału III Dyrekty-

18 Jednocześnie w motywie tym wskazano, że wyjątek od powyższej zasady dotyczy jedynie uprawnień objętych przepisami rozdziału III dyrektywy 2003/87/WE, które mają być sprzedawane na aukcji w latach 2011-2012 (tzw. wcześniejsze aukcje uprawnień, które dotyczyły 120 mln uprawnień i związane były z testowaniem systemu aukcyjnego jeszcze przed rozpoczęciem trzeciego okresu rozliczeniowego). 
wy 2003/87/WE, które są sprzedawane na aukcji") wolumen, który ma być sprzedany na aukcji w każdym roku kalendarzowym, powinien co do zasady odpowiadać ilości uprawnień ustalonych na podstawie art. 9 Dyrektywy 2003/87/WE na dany rok kalendarzowy ${ }^{19}$.

Powyższe reguły, będące podstawą obowiązującego tekstu Rozporządzenia 1031/2010, są bardzo czytelne. Na grunt Rozporządzenia 1031/2010 przeniesione zostały bowiem mechanizmy wyznaczone przez regulację art. 9 Dyrektywy 2003/87/ WE, a więc zasada określonego liniowego (1,74\%) spadku liczby uprawnień wydawanych w każdym kolejnym roku okresu rozliczeniowego. W ten sposób aukcje uprawnień mogą być prowadzone w sposób zharmonizowany, przejrzysty i przewidywalny, w szczególności w odniesieniu do szacunkowego wolumenu uprawnień, które mają być udostępnione, a więc zgodnie z zakresem delegacji do wydania Rozporządzenia 1031/2010 określonej w art. 10 ust. 4 Dyrektywy 2003/87/WE.

Tymczasem wdrożenie backloadingu powodującego opóźnienie aukcji znacznych ilości EUA w latach 2013-2015 zmierza w istocie do modyfikacji liniowego współczynnika będącego podstawą wydania określonych wolumenów EUA. Backloading wprowadzi więc zmianę istotnego dla całej regulacji EU ETS mechanizmu wyznaczającego ramy dystrybucji EUA.

Ponieważ postanowienia art. 9 Dyrektywy 2003/87/WE stanowią ważny element konstrukcji EU ETS, będący podstawą również przepisów Rozporządzenia 1031/2010, uzasadniony jest wniosek, iż mają one charakter kluczowy i ,istotny” dla Dyrektywy 2003/87/WE. Z powyższego płynie więc wniosek, że za sprzeczne $\mathrm{z}$ art. 290 ust. 1 TFUE należy uznać postanowienia Projektu zmiany Dyrektywy 2003/87/WE oraz Projektu zmiany Rozporządzenia 1031/2010. Rozwiązania przedstawione w tych projektach będą bowiem upoważniać Komisję do wydawania aktów delegowanych zmieniających istotny element Dyrektywy 2003/87/WE, jakim jest mechanizm wydawania

19 Liczba ta jest pomniejszona o określony przydział bezpłatnych uprawnień oraz o ewentualne drobne korekty przydziału uprawnień prowadzone na podstawie odrębnych przepisów. 
wolumenów uprawnień w poszczególnych latach okresu rozliczeniowego, oparty na określonym współczynniku liniowej redukcji emisji.

\subsection{BACKLOADING A ZAŁOŻENIA SYSTEMOWE EU ETS}

Niezależnie od powyższych wniosków dotyczących uchybień proceduralnych, projekt backloadingu nasuwa również krytyczne uwagi, jeżeli chodzi o jego zgodność: (i) z celami Dyrektywy 2003/87/WE, (ii) z podstawowymi założeniami EU ETS opartymi na mechanizmach rynkowych, a nie administracyjnych, (iii) z założeniami leżącymi u podstaw mechanizmu aukcyjnego, który powinien odzwierciedlać cenę notowanych instrumentów, a nie ją kształtować.

\subsubsection{Sprzecznoóć celów backloadingu z celami Dyrektywy 2003/87/WE}

Głównym założeniem leżącym u podstaw EU ETS jest to, by cena EUA kształtowana była przez mechanizmy rynkowe wspierane poprzez stopniową redukcję ilości dostępnych uprawnień zgodnie z art. 9 Dyrektywy 2003/87/WE. Podejście takie zapewnia kosztowo efektywny sposób realizacji zobowiązań redukcyjnych oraz ujęte zostało wśród celów Dyrektywy 2003/87/WE. Zgodnie z jej art. 1 niniejsza dyrektywa ustanawia system handlu przydziałami emisji gazów cieplarnianych [...] w celu wspierania zmniejszania emisji gazów cieplarnianych w efektywny pod względem kosztów oraz skuteczny gospodarczo sposób. Cel ten stanowił również podstawę rozwiązań przyjętych przez Dyrektywie 2009/29/WE20.

Uwzględniając powyższy cel Dyrektywy 2003/87/WE, krytycznie należy odnieść się do motywów leżących u podstaw backloadingu. Propozycja ta zmierza bowiem do podniesienia cen EUA za pomocą administracyjnej interwencji. Zgodnie z inten-

20 Zob. np. motyw (5), (8) czy motyw (13) Dyrektywy 2009/29/WE. 
cjami Komisji działanie to ma się przyczynić do stymulowania rozwoju technologii niskoemisyjnych (np. odnawialnych źródeł energii), ponieważ zdaniem Komisji przy obecnych cenach EUA na poziomie 4-5 euro nowe technologie nie są wystarczająco konkurencyjne.

Takie uzasadnienie propozycji backloadingu pomija szereg mechanizmów stworzonych $\mathrm{w}$ ramach EU ETS w celu dodatkowego finansowania inwestycji niskoemisyjnych. W szczególności można tu wskazać na obligatoryjny mechanizm finansowania tych inwestycji za pomocą środków uzyskanych ze sprzedaży EUA na aukcjach. Zgodnie z art. 10 ust. 3 Dyrektywy 2003/87/WE państwa członkowskie powinny przeznaczać przynajmniej 50\% środków uzyskanych ze sprzedaży na aukcji uprawnień (lub równowartość finansową tych dochodów) na rozwój energii ze źródeł odnawialnych lub gospodarki niskoemisyjnej. Ponadto mechanizmem, który ma wspierać rozwój inwestycji w niskoemisyjne technologie jest tzw. krajowy plan inwestycji finansowany za pomocą bezpłatnych uprawnień przyznawanych przejściowo wytwórcą energii. Zgodnie $\mathrm{z}$ art. 10c ust. 1 Dyrektywy 2003/87/WE dane państwo członkowskie przedkłada Komisji krajowy plan przewidujący inwestycje w zakresie modernizacji i poprawy infrastruktury oraz czystych technologii. Ponadto, zgodnie z art. 10a ust. 8 Dyrektywy 2003/87/ WE, do 300 mln EUA z rezerwy dla nowych instalacji jest dostępne do dnia 31 grudnia 2015 r. w celu wsparcia budowy i uruchomienia nie więcej niż 12 komercyjnych projektów demonstracyjnych, których celem jest bezpieczne dla środowiska wychwytywanie i geologiczne składowanie CO2 (CCS), oraz projektów demonstracyjnych w zakresie innowacyjnych technologii energetyki odnawialnej na terytorium Unii.

W kontekście wszystkich tych mechanizmów, które funkcjonują na gruncie Dyrektywy 2003/87/WE motywy leżące u podstaw backloadingu wydają się jeszcze mniej zasadne. Dodatkowe wsparcie finansowe niskoemisyjnych technologii zwiększa bowiem inwestycje $\mathrm{w}$ te technologie, co przyczynia się do obniżenia ich koszu (poprzez efekt skali) oraz zwiększa ich konkurencyjność. Z kolei z punktu widzenia celów EU ETS, jakim jest obniżanie emisji w efektywny kosztowo sposób, pod- 
niesienie samej ceny EUA może mieć odwrotny od zamierzonego skutek. Nadmierne strumienie finansowe, które będą trafiały do producentów rozwiązań niskoemisyjnych nie będą bowiem w wystarczającym stopniu stymulować spadku ceny tych urządzeń. Trudno taką sytuację uznać za rozwiązanie, które będzie kosztowo efektywnym sposobem ograniczania emisji.

\subsubsection{Zastąpienie mechanizmów rynkowych mechanizmami administracyjnymi}

Przepisy Dyrektywy 2003/87/WE w wielu miejscach odwołują się do rynkowego charakteru EU ETS ${ }^{21}$. Przejawem rynkowego charakteru tego systemu są aukcje uprawnień do emisji, których aspekt technicznie reguluje w szczególności Rozporządzenie 1031/2010. Dlatego też zasadne wydaje się, by zakres spraw regulowanych przez Rozporządzenie 1031/2010 (a więc kwestie techniczne związane $\mathrm{z}$ organizacją aukcji uprawnień) oddzielać od problematyki faktycznego poziomu cen kształtowanych przez rynek. Zgodnie z motywami Rozporządzenia 1031/2010 wykorzystywanie platform aukcyjnych/instrumentów aukcyjnych służyć powinno jedynie do odzwierciedlenia faktycznego sygnału cenowego czy też wzmocnienia sygnału cenowego $^{22}$, a nie do jego zniekształcania czy też modyfikacji. Dlatego też administracyjna ingerencja w rynek zmierzająca do podniesienia ceny EUA, której przejawem jest backloading, wydaje się sprzeczna z istotą regulacji aukcyjnych, które powinny zachować najdalej posuniętą neutralność cenową ${ }^{23}$. Podejście takie rodzi obawy, iż propozycja legislacyjna Komisji oraz jej uzasadnienie stanowić będzie podstawę do podejmowania

21 Zob. np. art. 12 ust. 1a, art. 29 czy art. 29a Dyrektywy 2003/87/WE.

22 Zob. motyw 4 Rozporządzenia 1031/2010.

23 Na marginesie można wskazać, iż Rezolucji Parlamentu Europejskiego z dnia 22 października 2008 roku, która poprzedzała przyjęcie pakietu energetyczno-klimatycznego, wskazano, że „cele UE w zakresie zmian klimatu na okres po 2012 r. nie powinny być kwestionowane na skutek obecnego międzynarodowego kryzysu finansowego [...]", (tekst przyjęty dnia 22 października 2008 roku, dok P6_TA(2008)0506). 
w przyszłości kolejnych kroków zmierzających do zwiększenia ceny EUA do bliżej niesprecyzowanego poziomu gwarantującego impuls do inwestycji w niskoemisyjne technologie.

\subsubsection{Zniekształcenie podstawy wydania Rozporządzenia 1031/2010}

Propozycja backloadingu wprowadza również pewną wewnętrzną sprzeczność w treści samej podstawy Rozporządzenia 1031/2010 (art. 10 Dyrektywy 2003/87/WE). Zgodnie z art. 10 ust. 4 tej dyrektywy do 30 czerwca 2010 roku Komisja zobowiązana była wydać rozporządzenie określające zharmonizowane zasady aukcji uprawnień, tak by podczas aukcyjnej sprzedaży uprawnień zapewnić realizację wskazanych w tym przepisie zasad w tym przewidywalności w odniesieniu do harmonogramu oraz szacunkowego wolumenu uprawnień, które mają być udostępnione. Projekt backloadingu zmierzający do rewizji Dyrektywy 2003/87/WE oraz Rozporządzenia 1031/2010, zmieniając harmonogram aukcji oraz wolumeny uprawnień w trakcie okresu rozliczeniowego, koliduje z tymi zasadami.

Regułą powinna być trwałość regulacji objętej Rozporządzeniem 1031/2010, co ściśle koresponduje z zasadą przewidywalności i przejrzystości. Warto wskazać, że wcześniejsza zmiana Rozporządzenia 1031/2010²4 (w postaci wcześniejszej możliwości sprzedaży uprawnień na aukcji) z założenia miała charakter wyjątkowy. Zmiana ta miała również swoje oparcie w Dyrektywie 2009/29/WE ${ }^{25}$. Zgodnie z motywem (20) tej dyrektywy, w celu zapewnienia zorganizowanego funkcjonowania rynku emisji CO2 i rynku energii elektrycznej, sprzedaż uprawnień na aukcji na okres rozpoczynający się w 2013 r. powinna rozpocząć się do 2011 r. i opierać się na jasnych i obiektywnych zasadach, określonych z odpowiednim wyprzedzeniem.

24 W dniu 23 listopada 2011 roku, Komisja wydała rozporządzenie (UE) nr 1210/2011 zmieniające rozporządzenie (UE) nr 1031/2010 w szczególności w celu określenia wolumenów uprawnień do emisji gazów cieplarnianych, które mają zostać sprzedane na aukcji przed 2013 r., Dz.Urz. UE L 308 24.11.2011, s. 2.

25 Na podstawie art. 3d ust. 3 i art. 10 ust. 4 Dyrektywy 2003/87/WE. 
Niewątpliwe jest więc, że wszelkie kolejne zmiany harmonogramu aukcyjnego nie wpływają na poprawę przejrzystości i przewidywalności sprzedaży aukcyjnej. Uzasadnienie wprowadzonej zmiany powinno mieć związek z samym mechanizmem aukcyjnym i zmierzać do właściwego ukształtowania tego mechanizmu lub też poprawy jego funkcjonowania (jak to miało miejsce w przypadku zmiany wprowadzonej przez Rozporządzenie 1210/2011 ${ }^{26}$ ). Proponowana obecnie przez Komisję zmiana harmonogramu aukcyjnego (a właściwie istotnego przesunięcia wolumenów uprawnień) motywowana jest sytuacją makroekonomiczną. Nie dotyczy więc poprawy samego mechanizmu aukcyjnego. Dlatego też projekt backloadingu wydaje się kolidować również z zasadami przejrzystości i przewidywalności, które leżą u podstaw regulacji objętych zakresem Rozporządzenia 1031/2010.

\subsubsection{Pominięcie istniejących mechanizmów ingerencji na rynku}

Dyrektywa 2003/87/WE nie określa mechanizmów administracyjnych, za pomocą których można by ograniczać pulę EUA kierowaną na aukcje. Dyrektywa ta, a w ślad za nią Rozporządzenie 1031/2010, opiera się bowiem na mechanizmie równomiernego (opierając się na liniowym współczynniku redukcji) wprowadzania do obrotu, z góry określonej liczby EUA.

Wyjątkiem od tej reguły są jedynie rozwiązania zawarte $\mathrm{w}$ art. 29a Dyrektywy 2003/87/WE27, zgodnie z którymi, jeżeli przez okres dłuższy niż sześć kolejnych miesięcy ceny uprawnień są ponad trzykrotnie wyższe od średniej ich ceny na europejskim rynku uprawnień w dwóch poprzednich latach

26 Zob. chociażby uzasadnienie do obecnej inicjatywy legislacyjnej Komisji Europejskiej - „[...] W 2011 r. zadecydowano o zmianie harmonogramu, przenosząc część wolumenu z 2013 i 2014 r. na rok 2012 w celu zapewnienia bezproblemowego przejścia $\mathrm{z}$ drugiego do trzeciego etapu [...].

27 Rozporządzenie 1031/2010 w art. 14 (Dostosowania kalendarza aukcji) zawiera odniesienie do art. 29a Dyrektywy 2003/87/WE. Oznacza to że w przypadku spełnienia przesłanek wskazanych w art. 29a dopuszczalne jest wprowadzenie modyfikacji kalendarza aukcji. 
i jeżeli ww. zmiany cen nie korespondują ze zmianą zasadniczych cech rynku, możliwe jest przyznanie upoważnienia państwom członkowskim do przyspieszenia sprzedaży na aukcji części liczby uprawnień albo dopuszczenie do sprzedaży na aukcji przez państwa członkowskie do $25 \%$ uprawnień z rezerwy dla nowych instalacji. Przepis ten zakłada więc możliwość wprowadzenia dodatkowej ilości uprawnień na rynek w celu obniżenia ceny EUA jeżeli dysproporcja cenowa zaobserwowana w dłuższym okresie czasu jest wyraźna (trzykrotna różnica ceny) oraz jeżeli nie ma to związku z ogólnymi trendami rynkowymi.

Należy zwrócić uwagę, że przesłanki zastosowania tego artykułu są szczegółowe, istnieje więc realna możliwość weryfikacji ich wystąpienia. Istotne jest również to, że motywy wprowadzenia tego rozwiązania powiązane są z celami Dyrektywy 2003/87/WE tzn. mają przyczyniać się do zmniejszania emisji gazów cieplarnianych w efektywny pod względem kosztów sposób. Mechanizm ten nakierowany jest bowiem na obniżenie ceny EUA. Ingerencja w poziom cen musi opierać się dodatkowo na sprawozdaniach przedłożonych przez Komisję Parlamentowi Europejskiemu i Radzie przygotowywanych na podstawie odpowiednich danych dotyczących funkcjonowania mechanizmu aukcyjnego w poszczególnych państwach.

Warto również podkreślić, iż wprowadzenie tej regulacji ma swoje bardzo istotne uzasadnienie. Artykuł 29a Dyrektywy 2003/87/WE ma chronić podmioty zobowiązane do corocznego umarzania uprawnień przed nadmiernymi kosztami uczestnictwa $\mathrm{w}$ systemie. Jasne jest, że ten mechanizm poprzez odpowiednią modyfikację ustalonego zgodnie z Rozporządzeniem 1031/2010 harmonogramu aukcyjnego doprowadzić ma do faktycznego spadku nienaturalnie wysokich cen uprawnień na rynku. Jest to zgodne z zasadą ograniczenia emisji gazów cieplarnianych jak najniższym kosztem. Dodatkowy argument, jaki płynie z ww. regulacji art. 29a oraz środków znajdujących zastosowanie na podstawie tego przepisu, to to, że w świetle Dyrektywy 2003/87/WE istnieje ścisły związek pomiędzy ilością uprawnień na rynku a ich ceną (ilość uprawnień na rynku wpływa odpowiednio na ich cenę). 
Porównanie powyższej regulacji oraz podstaw jej zastosowania wskazuje na istotne różnice w stosunku do przesłanek leżących u podstaw backloadingu. Projekt backloadingu nie zawiera bowiem odpowiednika przepisu ww. art. 29a oraz mechanizmów obiektywnej weryfikacji ingerencji w rynek. Zastosowanie backloadingu opiera się na całkowitym uznaniu Komisji odnośnie do prawidłowego funkcjonowania rynku bez podania weryfikowalnych i obiektywnych kryteriów takiej oceny.

\section{KONKLUZJE}

Zgodnie z art. 263 oraz 267 TFUE kontrola legalności aktów organów Unii zastrzeżona została do kompetencji TSUE. Naruszenie istotnych wymogów proceduralnych, jak również naruszenie traktatów, stanowi podstawę do stwierdzenia przez TSUE nieważności danego aktu (art. 264 TFUE). Zgodnie z utrwalonym orzecznictwem TSUE sądy krajowe nie mają kompetencji do stwierdzania nieważności aktów instytucji Unii. Do stwierdzenia nieważności aktu Unii takiego jak dyrektywa czy rozporządzenie właściwym jest TSUE ${ }^{28}$.

Powyższe oznacza, iż mimo jak się wydaje bezdyskusyjnych uchybień Projektu zmiany Dyrektywy 2003/87/WE oraz Projektu zmiany Rozporządzenia 1031/2010, a w szczególności sprzeczności tych projektów z art. 290 ust. 1 TFUE, akty prawne przyjęte na podstawie tych projektów mogą w niemal natychmiastowy i nieodwracalny sposób na nowo ukształtować sytuację uczestników EU ETS. Zgodnie bowiem z propozycją backloadingu, skutek tych regulacji w postaci zmniejszenia o $900 \mathrm{mln}$ puli EUA kierowanych na aukcje nastąpić powinien już w roku 2013. Przeciwstawienie się skutkom backloadingu w postaci wzrostu ceny EUA będzie możliwe jedynie w przypadku wniesienia skargi o stwierdzenie nieważności tej regulacji wraz ze

28 Zob. wyrok TSUE z dnia 21 grudnia 2011 r. w sprawie C-366/10, pkt 46-48 oraz przywołane tam orzecznictwo, 
skutecznym wnioskiem o zastosowanie środków tymczasowych (np. wstrzymanie wykonalności nowych regulacji) ${ }^{29}$.

Skargę taką musiałoby w zasadzie wnieść któreś z państw członkowskich. Analiza orzecznictwa ${ }^{30}$ TSUE, wskazuje bowiem na znaczne ryzyko oddalenia skargi jednostki (osoby fizycznej lub prawnej) jako niedopuszczalnej ze względu na brak bezpośredniego i indywidulanego związku omawianych tu projektów z sytuacją takich jednostek ${ }^{31}$.

\section{Kontakt e-mail:}

piotr.czembor@op.pl; piotr.czembor@dentons.com

29 Przeciętna długość rozpoznawania spraw w 2012 r. różniła się w zależności od sądu unijnego oraz rodzaju postępowania. W Trybunale średni czas rozpatrywania odesłań prejudycjalnych wynosił 15,7 miesiąca, skarg bezpośrednich 19,7 miesiąca, natomiast odwołań 15,3 miesiąca. Możliwe jest również rozpoznawanie sprawy w ramach procedur szczególnych (trybie przyspieszonym, trybie uproszczonym, lub pilnym rybie prejudycjalnym z zastrzeżeniem spełnienia przesłanek któregoś z tych trybów). Czas trwania takich postępowań może zamknąć się nawet w terminie 2 miesięcy [dane na podstawie Sprawozdania rocznego TSUE 2012]. Możliwe jest również zastosowanie środków tymczasowych, w ramach których można wnioskować o zawieszenie wykonania zaskarżonego aktu wydanego przez instytucję UE.

30 Zob. np. postanowienie z dnia 23 września 2008 r. w sprawie T-203/07; postanowienie z dnia 2008 r., w sprawie T-208/07.

31 Zgodnie z art. 263 TFUE, każda osoba fizyczna lub prawna może wnieść, na warunkach przewidzianych w akapitach pierwszym i drugim, skargę na akty, których jest adresatem lub które dotyczą jej bezpośrednio i indywidualnie oraz na akty regulacyjne, które dotyczą jej bezpośrednio i nie wymagają środków wykonawczych. 